\title{
Circadian variation of fatigue in both patients with paralytic poliomyelitis and post-polio syndrome
}

\author{
Variação circadiana da fadiga em ambos os grupos de pacientes \\ com poliomielite paralítica e síndrome pós-poliomielite \\ Celiana Figueiredo Viana', Márcia Pradella-Hallinan², Abrahão Augusto Juviniano Quadros², \\ Luis Fabiano Marin ${ }^{3}$, Acary Souza Bulle Oliveira ${ }^{4}$
}

\begin{abstract}
Objective: It was to evaluate the degree of fatigue in patients with paralytic poliomyelitis (PP) and with post-polio syndrome (PPS), and correlate it with parameters of sleep and the circadian cycle. Methods: Thirty patients, 17 female (56.7\%), participated in the study: they answered the Revised Piper Fatigue Scale and performed a nocturnal polysomnographic study. Eleven had PP (mean age \pm standard deviation of 47.9 \pm 6.4 years), and 19 had PPS (mean age \pm standard deviation of $46.4 \pm 5.6$ years). Results: Our study showed that fatigue was worse in the afternoon in the PP Group and had a progressive increase throughout the day in the PPS Group. We also observed compromised quality of sleep in both groups, but no statically significant difference was found in the sleep parameters measured by polysomnography. Conclusion: Fatigue has a well-defined circadian variation, especially in PPS Group. Poor sleep quality is associated with fatigue and, therefore, sleep disturbances should be evaluated and treated in this group of PPS.
\end{abstract}

Key words: fatigue, poliomyelitis, postpoliomyelitis syndrome, sleep, circadian.

\section{RESUMO}

Objetivo: Foi avaliar o grau de fadiga em pacientes com poliomielite paralítica (PP) e com síndrome pós-poliomielite (SPP), e correlaciona-lo com parâmetros de sono e ciclo circadiano. Método: Trinta pacientes, 17 do sexo feminino (56,7\%), participaram do estudo: responderam à Escala de Fadiga de Piper Revisada e submeteram-se à avaliação polissonográfica noturna. Onze apresentavam PP (média de idade \pm desvio

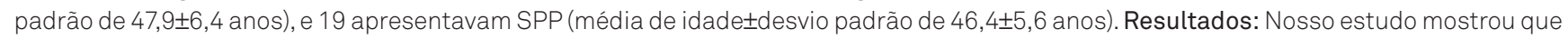
a fadiga é pior no período da tarde no grupo com PP e piora progressivamente ao longo do dia no grupo SPP. Observamos também comprometimento na qualidade do sono em ambos os grupos. Contudo, os parâmetros do sono avaliados pela polissonografia não demonstraram diferenças estatísticas significantes entre os grupos PP e SPP. Conclusão: A fadiga apresenta variação circadiana bem definida, especialmente nos pacientes do grupo SPP. Pobre qualidade do sono está associada com fadiga e, portanto, distúrbios do sono deveriam ser mais bem avaliados e tratados no grupo de pacientes com SPP.

Palavras-Chave: fadiga, poliomielite, síndrome pós-poliomelite, sono, circadiano.

After a long period of stability following a polio virus infection, patients with or without sequelae of poliomyelitis may develop new disabilities with a wide range of symptoms, which can be consistent with the post-polio syndrome (PPS)'. The clinical manifestation of PPS includes a new muscle weakness, progressive muscle atrophy, fatigue, cold intolerance, muscular and joint pain, respiratory and swallowing distress, and sleep disturbances ${ }^{23}$.
Fatigue is a common symptom in polio survivors, especially in PPS, occurring in 49-89\% of post-polio patients ${ }^{4}$. Little is known about the circadian variation of fatigue in polio survivors and their correlation with sleep parameters. Herein, our objective was to evaluate the fatigue degree in a cohort of patients with paralytic poliomyelitis (PP) and with PPS, and to correlate with sleep parameters from polysomnography and the circadian cycle.

\footnotetext{
Neuromuscular Disorders Unit, Department of Neurology and Neurosurgery, Universidade Federal de São Paulo (UNIFESP), São Paulo SP, Brazil. ${ }^{1}$ Pós-Graduanda do Departamento de Neurologia, Universidade Federal de São Paulo/Escola Paulista de Medicina (UNIFESP/EPM), São Paulo SP, Brazil; ${ }^{2}$ Doutora em Ciências, Departamento de Medicina do Sono, UNIFESP/EPM, São Paulo SP, Brazil;

${ }^{3}$ Doutor em Ciências, Departamento de Neurologia, UNIFESP/EPM, São Paulo SP, Brazil;

${ }^{4}$ Professor Afiliado, Departamento de Neurologia, UNIFESP/EPM, São Paulo SP, Brazil.

Correspondence: Celiana Figueiredo Viana; Rua Estado de Israel 899; 04022-002 São Paulo SP - Brasil; E-mail: celianafigueiredo@hotmail.com Conflict of interest: There is no conflict of interest to declare.

Received 10 September 2012; Received in final form 19 February 2013; Accepted 26 February 2013.
} 


\section{METHODS}

Forty-two consecutive patients with previous polio infection, who visited the outpatient care center of the Neuromuscular Disorders Unit of the Universidade Federal de São Paulo, were evaluated for this study. We consider for the study only patients with PP and with symptoms of PPS who had fatigue complain. All patients had sequelae of poliomyelitis confirmed by clinical history, neurological examination and by electroneuromyography. PPS diagnosis was performed according to Mulder et al. criteria $a^{5}$ and according to the March of Dimes International Conference on PPS in $2000^{6}$.

All patients complained of fatigue and answered on the Revised Piper Fatigue Scale. This scale is a multidimensional tool of self-report for fatigue evaluation. The Brazilian version of the Revised Piper Fatigue Scale was developed in 1998 from the Piper Fatigue Scale and validated in Brazil by Mota et al. ${ }^{7}$. It is composed of 22 questions distributed in 3 aspects: behavioral (items 2 to 7 ), affective (items 8 to 12) and psychological sense (items 13 to 23). The patients were instructed to answer the scale in their homes, in a period of 7 consecutive days. The scale was applied every day in the morning ( 9 a.m.), in the afternoon (3 a.m.) and in the evening (9 p.m.). Patients had also to report what time of the day fatigue was more intense.

Daytime sleepiness was assessed by the Epworth Sleepiness Scale (ESS). Patients were considered with excessive daytime sleepiness if they scored more than ten points.

To evaluate the parameters of sleep, patients underwent a full-night polysomnographic study (PSG) (Alice Host Polygraph, Respironics). Variables analyzed in PSG included: total sleep time, sleep efficiency, sleep latency, rapid eye movement (REM) sleep latency, percentage of sleep 1 stage, percentage of sleep 2 stage, percentage of sleep 3 and 4 stage, percentage of rapid eye movement sleep stage, periodic limb movements in sleep (PLM), total arousal index and apnea-hypopnea index (AHI). Awakenings, respiratory events and PLM were analyzed according the American Academy of Sleep Medicine?.

Exclusion criteria included patients over 59 years; systemic diseases which fatigue may occur, such as: anemia, thyroid dysfunction, diabetes, fibromyalgia, cancer, pneumopathy, hepatopathy, acute or chronic renal dysfunction, AIDS and congestive heart failure.

This study was approved by the Ethics and Research Committee of the Universidade Federal de São Paulo (process number: 1320/07), and all patients were informed about the nature and details of the study and signed a written informed consent.

\section{RESULTS}

A total of 42 consecutive patients were evaluated for the study. Of them, 12 individuals did not meet the initial criteria and were excluded from this study. Of the 30 remaining patients, 17 were female $(56.7 \%)$ and 13 were male $(43.3 \%)$. Eleven had PP (mean agetstandard deviation of $47.9 \pm 6.4$ years), and 19 had PPS (mean age \pm standard deviation of $46.4 \pm 5.6$ years). Individuals with PP had a mean mass body index of $29.5 \pm 3.1 \mathrm{~kg} / \mathrm{m}^{2}$, and with PPS, 26.4 \pm 5.6 (Table 1).

No statistically significant difference was found between the groups in relation to the sociodemographic aspects: age, weigh, years of school instruction and mass body index (comparisons made through $\chi^{2}$ test and Student's $t$-test).

Information related to the 23 questions of the Piper Fatigue Scale was analyzed question by question:

- The analysis of the behavioral aspect (questions 2 to 7 ) did not indicate any statistically significant difference during the day in the PP Group, except for the question

Table 1. General characteristics of the sample.

\begin{tabular}{|c|c|c|c|c|c|}
\hline & \multicolumn{2}{|c|}{ PP Group } & \multicolumn{2}{|c|}{ PPS Group } & \multirow{2}{*}{$p$-value } \\
\hline & $\mathrm{n}$ & Mean (SD) & $\mathrm{n}$ & Mean (SD) & \\
\hline Age (years) & 11 & $47.9(6.4)$ & 19 & $46.4(5.3)$ & 0,48 \\
\hline \multirow[t]{2}{*}{ BMI $\left(\mathrm{kg} / \mathrm{m}^{2}\right)$} & 11 & $25.9(3.1)$ & 19 & 26.4 (5.6) & 0,10 \\
\hline & $\mathrm{n}$ & $\%$ & $\mathrm{n}$ & $\%$ & \\
\hline Gender & & & & & 0,86 \\
\hline Male & 5 & 45 & 8 & 42 & \\
\hline Female & 6 & 55 & 11 & 58 & \\
\hline Years of study & & & & & 0,87 \\
\hline 8 years & 4 & 36 & 6 & 32 & \\
\hline 11 years & 1 & 9 & 1 & 5 & \\
\hline $15-16$ years & 6 & 55 & 12 & 63 & \\
\hline
\end{tabular}

PP: paralytic poliomyelitis; PPS: post-polio syndrome; SD: standard deviation; BMI: body mass index. 
Table 2. Sleep parameters obtained by polysomnography.

\begin{tabular}{|c|c|c|c|c|c|c|c|}
\hline & \multicolumn{3}{|c|}{ PP Group } & \multicolumn{3}{|c|}{ PPS Group } & \multirow{2}{*}{$\frac{\mathrm{p} \text {-value }}{t \text {-test }}$} \\
\hline & $\mathrm{n}$ & Mean & SD & $\mathrm{n}$ & Mean & SD & \\
\hline Total sleep time (min) & 11 & 313.0 & 87.5 & 19 & 338.7 & 54.9 & 0.33 \\
\hline Sleep efficiency (\%) & 11 & 68.8 & 16.6 & 19 & 73.7 & 11.2 & 0.35 \\
\hline REM latency (min) & 11 & 133.7 & 94.3 & 18 & 120.5 & 63.2 & 0.65 \\
\hline Sleep latency (min) & 11 & 29.9 & 13.8 & 19 & 47.3 & 40.6 & 0.18 \\
\hline Index of awakenings & 11 & 11.9 & 6.4 & 19 & 17.4 & 10.9 & 0.14 \\
\hline Stage 1 (\%) & 11 & 2.4 & 1.3 & 19 & 4.0 & 3.2 & 0.13 \\
\hline Stage $2(\%)$ & 11 & 64.5 & 17.3 & 19 & 62.6 & 14.1 & 0.74 \\
\hline Stage $3(\%)$ & 11 & 2.5 & 1.9 & 19 & 2.3 & 1.1 & 0.66 \\
\hline Stage 4 (\%) & 11 & 10.6 & 11.1 & 19 & 10.4 & 7.1 & 0.96 \\
\hline REM (\%) & 11 & 20.0 & 9.1 & 19 & 20.7 & 8.5 & 0.83 \\
\hline
\end{tabular}

PP: paralytic poliomyelitis; PPS: post-polio syndrome; SD: standard deviation; REM: rapid eye movement.

7, which is about the fatigue intensity. In the PPS Group, the average score of these questions increased statistically during the day, except the question 4, which is about the capacity of visiting a friend.

- The analysis of the affective aspect (questions 8 to 12) did not indicate any statistically significant difference during the day in the PP Group, except for the question 8, which is about the fatigue subjective perception. In the PPS Group, the score of these questions increased statistically during the day, except the question 8 .

- The analysis of the sensorial aspect (questions 13 to 23) did not indicate any statistically significant difference during the day in the PP Group, but in the PPS Group the analysis demonstrated statistically significant difference in the subject's capacity of thinking clearly (question 23).

Regarding the Epworth Sleepiness Scale, the mean ESS score in PP and in PPS Groups was, respectively, 7.8 \pm 3.3 and $7.9 \pm 4.6$ points.

Sleep parameters analyzed by polissomnography showed: reduced sleep efficiency in PP Group (meantstandard deviation of $68.8 \pm 16.6 \%$ ) and in PPS Group (mean \pm standard deviation of $73.7 \pm 11.2 \%$ ); increased sleep latency in PP (mean \pm standard deviation of $29.9 \pm 13.8$ minutes) and in PPS Group (mean \pm standard deviation of $47.3 \pm 40.6$ minutes) (Table 2).

In PP Group, there were no PLM in all patients studied. In PPS Group, 12 patients (63\%) showed no PLM and the other 7 (37\%) showed a wide variation in the PLM index, ranging between 12 and 73 events per hour. In PP Group, the apneahypopnea index (AHI) was normal in $8(73 \%)$ patients and the other 3 (27\%) had an AHI between 6.4 and 21.1 events per hour. In PPS Group, the AHI was normal in 13 (68\%) patients and the other 6 (32\%) had an AHI between 7.3 and 41.9 events per hour (Table 2).

No statistically significant difference was found between PP and PPS Groups in any of the analyzed PSG study parameters.

\section{DISCUSSION}

Our study showed that fatigue has a circadian variation in both patients with PP and with PPS, predominantly in the afternoon in PP Group and progressively getting worse throughout the day in PPS Group.

Fatigue is a common symptom in polio survivors and it can be multifactorial. It can also be of physical or mental character and it is postulated that it may be caused by early neuronal damage in the brain in the acute poliomyelitis stage, or influenced by psychological factors, or muscular from the motor unit, or an overlap of these factors ${ }^{10}$. Particularly in patients with PPS, fatigue may start or intensify with excessive physical activity or emotional stress ${ }^{11}$.

Sleep disturbances, such as insomnia, periodic limb movements during sleep, restless legs syndrome and obstructive sleep apnea, may be associated with poor sleep quality and fatigue $\mathrm{e}^{12-14}$. In our patients, PSG showed altered sleep architecture, increased AHI and increased PLM index during sleep, especially in PPS Group. Even analysis revealing no statistically significant difference in both groups, we believe that sleep disturbances could play a role in increasing the fatigue. Perhaps, a weakness of our study to better establish the relationship between fatigue and altered sleep parameters can be related to the small sample of patients studied. We also did not evaluate whether our patients had other sleep disorders that could also decrease the quality of sleep as insomnia and restless legs syndrome.

In conclusion, fatigue is one of the most frequent complains in polio survivors and it may be an important limiting factor that can worse the motor function and pain and reduce the functional capacity. We believe that knowing what period of the day fatigue is more intense can help in developing strategies to improve the quality of life of these individuals. Otherwise, treating sleep disorders can also play an important role in reducing fatigue. Further studies are now welcome to evaluate possible mechanisms related to the circadian variation of fatigue in this group of patients. 


\section{References}

1. Laffont I, Julia M, Triffream V, Yelnik A, Harisson C, Pelissier J. Aging and sequelae of poliomyelitis. Ann Phys Rehab Med 2010;53:24-33.

2. Trojan DA, Cashman NR. Pathophisiology and diagnosis of post-polio syndrome. Neurorehabilitation 1997;8:83-92.

3. Trojan DA, Cashman NR. Post-poliomyelitis syndrome. Muscle- Nerve 2005:31:6-19.

4. Strohschein FJ, Kelly CG, Clark AG, Westbury CF, Shuaib A, Chan KM Applicability, validity, and reliability of the Piper Fatigue Scale in postpolio patients. Am J Phys Med Rehabil 2003;82:122-129.

5. Mulder DW, Rosenvaum RA, Layton DD. Late progression of poliomyelitis or forme fruste amyotrophic lateral sclerosis? Mayo Clin Proc 1972; 47:756-761.

6. March of Dimes. Post-polio syndrome: identifying best practices in diagnosis and care. White Plains, NY: March of Dimes Birth Defects Foundation [cited 2012 Aug 20]. Available from: www.marchofdimes.com

7. Mota DDCF, Pimenta CAM, Piper BP. Fatigue in Brazilian cancer patients, caregivers, and nursing students: a validation study of the Piper Fatigue Scale - Revised. Support Care Cancer 2009;17:645-652.
8. Johns MW. A new method for measuring daytime sleepiness: the Epworth sleepiness scale. Sleep 1991;14:540-545.

9. American Academy of Sleep Medicine Task Force. Sleep-related breathing adults: recommendations for syndrome definition and measurement techniques in clinical research. Sleep 1999;22:667-689.

10. Henrik Gonzalez, Tomas Olsson, Kristian Borg. Management of postpolio syndrome. Lancet Neurol 2010;9:634-642.

11. Bruno RL, Sapolsky R, Zimmerman JR, Frick NM. Pathophysiology of a central cause of post-polio fatigue. Ann NY Acad Sci 1995;25:753-757.

12. Bailes S, Libman E, Baltzan M, et al. Fatigue: the forgotten symptom of sleep apnea.J Psychosom Res 2011;70:346-54

13. Riedel BW, Lichstein KL. Insomnia and daytime functioning. Sleep Med Rev 2000;4:277-298.

14. Oliveira AR, Correa FI, Correa JC, Oliveira LV. Analysis of fatigue associated to periodic limb movement during sleep in former poliomyelitis patients. Rev Neurol 2012;54:24-30. 